\title{
Beef cattle farmers behavior toward biosecurity
}

\author{
V.S. Lestari ${ }^{1}{ }^{1 *}$, D. P. Rahardja ${ }^{2}$, P. Mappigau ${ }^{1}$, S.T. Rohani ${ }^{1}$ and S.N. Sirajuddin ${ }^{1}$ \\ ${ }^{1}$ Department of Socio-Economics, Faculty of Animal Husbandry, Hasanuddin University \\ Jl. Perintis Kemerdekaan Km. 10 Makassar 90245, South Sulawesi - Indonesia \\ ${ }^{2}$ Department of Animal Production, Faculty of Animal Husbandry, Hasanuddin University \\ Jl. Perintis Kemerdekaan Km. 10 Makassar 90245, South Sulawesi - Indonesia \\ *Corresponding E-mail: veronicasrilestari@unhas.ac.id
}

Received November 26, 2018; Accepted February 18, 2019

\begin{abstract}
ABSTRAK
Ternak sapi potong merupakan penghasil daging yang bermanfaat bagi manusia. Tujuan penelitian ini adalah untuk mengetahui dan mengendalikan perilaku peternak sapi potong terhadap penerapan biosekuriti di Kecamatan Lamasi - Kabupaten Luwu, Propinsi Sulawesi Selatan,. Jenis penelitian ini adalah penelitian deskriptif. Metode penelitian yang dilakukan adalah berupa survey, partisipatory research dan Focus Group Discussion. Jumlah sampel adalah 50 peternak sapi potong. Data diperoleh melalui wawancara dengan menggunakan kuesioner dan observasi. Alat analisis yang digunakan dalam penelitian ini adalah statistik deskriptif. Skala likert 1 sampai 3 digunakan untuk mengetahui ketidaksetujuan dan kesetujuan peternak sapi potong terhadap penerapan biosekuriti. Hasil penelitian menunjukkan bahwa peternak sapi potong kurang setuju terhadap adopsi biosekuriti. Berdasarkan norma subyektif, peternak akan mengadopsi biosekuriti jika didukung oleh tokoh masyarakat dan peternak lainnya atau kelompok tani. Pengendalian perilaku yang menjadi kendala utama untuk menerapkan biosekuriti adalah faktor kebiasaan, implementasi sebelumnya dan risiko, sedangkan faktor pendukungnya adalah membutuhkan waktu, dapat diuji pada usaha ternak skala kecil, sesuai dengan kebutuhan peternak, memerlukan tenaga kerja, pengetahuan, keterampilan, dan informasi tentang biosekuriti. Berdasarkan hasil penelitian ini, perlu diberikan motivasi kepada peternak sapi potong untuk mengadopsi biosekuriti supaya mendapatkan sapi potong yang sehat.
\end{abstract}

Kata kunci: : adopsi, biosekuriti, perilaku, peternak sapi potong

\begin{abstract}
Beef cattle are meat producers which are beneficial to humans. The purpose of this study was to identify and to control the behavior of beef cattle farmers towards biosecurity in Lamasi District - Luwu Region, South Sulawesi Province. This type of research was descriptive research. The research method was survey to participatory research and the Focus Group Discussion. Total sample was 50 respondents. Data were obtained through interview using questionnaires and observations. Data were analyzed using descriptive statistic. Likert scale 1 until 3 were used to know the response level of disagree and agree about biosecurity. The results showed that beef cattle farmers less agree to biosecurity adoption. Based on subjective norm, farmers' behaviors agree to adopt biosecurity if they were supported by community leaders and other livestock farmers or farmer groups. Behavior control which becomes the main obstacles to implementing biosecurity are habits, prior implementation and risks. The supporting factors needed time, can be tested on a small scale cattle business, according to the needs of cattle farmers, needed workers, needed knowledge, skills, and information about biosecurity. Beef cattle farmers should
\end{abstract}


be motivated to adopt biosecurity in order to get a healthy beef cattle.

Keywords: adoption, behavior, beef cattle farmers,

\section{INTRODUCTION}

Beef cattle is one of commodity which are important to be developed (Ekowati et al., 2018). Bali cattle (Bos javanicus) is a well-known origin cattle from Indonesia which was once used as meet producer to fulfill the required meat in Indonesia. This cattle additionally appropriate maintained by small farmer in Indonesia (Martojo, 2012).

Beef cattle breeders in Indonesia in general and in the province of South Sulawesi specifically rearing beef cattle in a traditional and simple technology, namely livestock released in the garden or yard, feeding in the form of field grass with low nutritional value, make shift cages, ownership between $2-3$ animal. As a result, the productivity of beef cattle is low. Until now, meat demand cannot be met by domestic production. There is a gap between meat consumed by the people and meat production, so that imports are needed in the form of calves and frozen meat. To increase domestic meat production, the government has carried out several programs, one of which is biosecurity.

According to the Republic of Indonesia Government Regulation No: 47 in 2014 concerning Animal Disease Control (Directorate General of Livestock and Animal Health, 2014), biosecurity is a motion which is the first defense for outbreak control and is carried out to forestall all feasible contact/transmission with contaminated livestock and spread of disease. The software of biosecurity in all farm animals sectors each in the poultry industry and other farms will limit the danger of spreading disease-causing microorganisms that threaten the sector. Biosecurity is administration in a cage consisting of vaccinations, sanitation and animal traffic management. The motive of making use of biosecurity is to prevent the transmission of livestock by zoonozis hazardous diseases, specifically ailments from cattle that can be transmitted to humans, such as Anthrax.

Aziz (2016) stated that the population of beef cattle in Lamasi District was 27,963 heads. The beef cattle breeding system is semi intensive, meaning that in the afternoon is released in the garden, and in the night is kept in barn. This rearing system is very susceptible to disease transmission. Therefore, to prevent cattle from contracting the disease, biosecurity needs to be applied.

Satyanarayana et al. (2008) stated that biosecurity focuses on maintaining the health standing of animals and preventing the entry of latest illness pathogens by assessing all attainable risks for animal health. Dorea et al. (2010) argued that biosecurity is a very important part of animal health programs. Siekkinen et al. (2012) stated that biosecurity is applied to the complete production chain. Several risk management practices are ceaselessly conducted irrespective of whether or not there's virus or not. Stancovie et al. (2011) argued that biosecurity indicators include written biosecurity plans, isolation, new arrived bovine treatment, animal health, instrumentality hygiene, control, waste management, beast carcasses, stock man management of alternative animals like rats and birds and sanitation.

Gunn et al. (2007) found that farmers and veterinarians have their own comparatively clear definitions for biosecurity. Farmers believe that the government ought to build a bigger contribution towards biosecurity. Conversely, in keeping with veterinary practitioners, their clients' ability or disposition to take a position in biosecurity measures as a significant constraint.

Adoption is a process that occurs from the first time someone hears something new until the person adopts (accepts, applies, uses) the new thing (Ibrahim et al., 2003). Acceptance of these innovations, usually can be observed directly or indirectly by others, as a reflection of the changes in attitudes, knowledge, and/or skills (Mardikanto, 2009). In step with Rogers (2003), there have been 5 stages within the adoption method as follows: awareness stage, interest stage, analysis stage, trial stage and adoption stage. There are 5 main characteristics of innovations that verify however associate in nursing innovation are going to be more matured by a possible farmer/end-user:

- Relative Advantage - The degree to that associate innovation is seen as higher than the thought, program, or product it replaces.

- Compatibility - How consistent the innovation is with the values, experiences, and desires of the potential adopters. 
- Complexity - How difficult the innovation is to understand and/or use.

- Trial ability - The extent to that the innovation may be tested or experimented with before a commitment to adopt is formed.

- Observability - The extent to that the innovation provides tangible results.

Behavior of breeders toward biosecurity can be approached with behavioral theory specifically Theory of Planned Behavior (TPB) is presented in Figure 1. According to Ajzen (2002), there are 3 main predictors that influence the intention of individual behavior, namely 1) attitudes toward the behavior which is a disposition or tendency to respond to things that are evaluative, favored or disliked by an object, person, institution or event. 2) subjective norms which are individual perceptions of social pressure to display or not display behavior, and 3) perception of behavioral control which is the perception of individual beliefs related to how individuals can do certain events.

The TPB has been used extensively to predict various kinds of behaviors, including agricultural behavior. Herath (2013) found that intention has explained the behavior. The angle, the perceived behavioral management, the farmers' age and also the farmers' education showed a major relationship with behavior. In this study the TPB was used to identify and to control beef cattle farmers behavior toward biosecurity.

\section{MATERIALS AND METHODS}

The design of this study is a Survey based on Theory of Planned Behavior (STPB). The type of research used in this study is quantitative descriptive. The population in this research is a whole household of beef cattle farmers in Lamasi District of Luwu Region amounted to 98. According to Slovin formula, total sample was 50 respondents. The sample were chosen by random sampling. Slovin formula:

Where:

$$
\mathrm{n}=\frac{\mathrm{N}}{1+\mathrm{Ne}^{2}}
$$

$$
\begin{array}{ll}
\mathrm{n} & =\text { number of sample } \\
\mathrm{N} & =\text { number of population } \\
\mathrm{e} & =\text { precision }(10 \%)
\end{array}
$$

The final STPB questionnaire contained 24 statements. Attitude can be defined as the behavior which is a disposition or tendency to respond, favored or disliked to biosecurity. To know the attitude of beef cattle farmers, there were 9 statements namely:

1. I think that by adopting biosecurity would be benefit

2. I think that by adopting biosecurity would be accordance with local custom or culture

3. I think that by adopting biosecurity would be in accordance with the environmental

4. conditions of local communities

5. I think that by adopting biosecurity would be in accordance with the needs of breeders

6. I think that by adopting biosecurity would be complicated

7. I think that by adopting biosecurity would be easily observed

8. I think that by adopting biosecurity would be tried on a small scale

9. I think that by adopting biosecurity would be increase meat production

10. I think that by adopting biosecurity would be improve the quality of beef

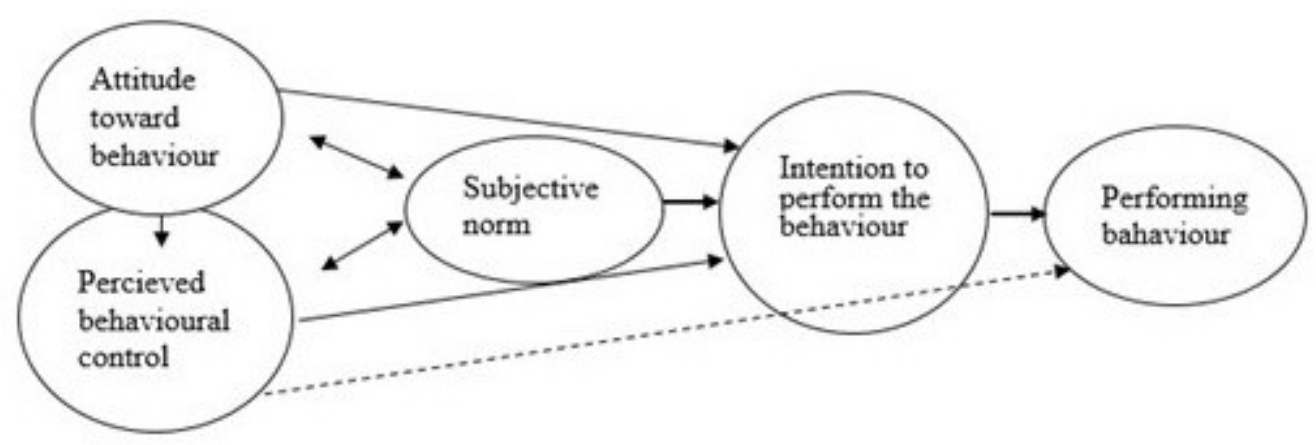

Figure 1. Theory of Planned Behavior (Ajzen, 2002) 
Subjective norms are individual perceptions of social pressure to display or not display behavior. Subjective norms consisted of 4 statements:

1. People (community leaders) who are important to me would think I should adopt biosecurity in my beef cattle farm.

2. People (government) whose opinion I value would think I should adopt biosecurity in my beef cattle farm.

3. My family (e.g. parents, siblings) think I should adopt biosecurity in my beef cattle farm.

4. My peers (farmers or other farmers group) would approve of my adoption to biosecurity.

Perception of behavioral control which is the perception of individual beliefs related to how individuals can apply biosecurity. There were 9 statements:

1. The application of biosecurity takes a long time to begin preparing until using it (time)

2. The application of biosecurity used to beef cattle farmers (habits)

3. The application of biosecurity can be tested on a small scale beef cattle farmers (triability)

4. The application of biosecurity in accordance with the needs of cattle farmers (compatibility)

5. Based on past experience, implementing biosecurity does not provide satisfactory results (prior implementation)

6. The application of biosecurity in beef cattle farms is more risky than without biosecurity (risk)

7. The application of biosecurity is lack of workforce (human resources)

8. The application of biosecurity is lack of knowledge and skills (training)

9. The application of biosecurity is lack of informations (informations)

The data collected in the research consisted of primary data and secondary data. The primary data were collected by observation and deep interview using questionnaires. Interviews with these respondents consisted of beef cattle behavior on the application of biosecurity. According to Riduwan and Adon (2009), likert scale used in this study consisted of disagree refer to score 1, less agree given score 2 and agree given a score of 3 . Analysis of research data will be done with quantitative descriptive analysis by using mean, percentage, and frequency distribution table.

\section{RESULTS AND DISCUSSIONS}

\section{Characteristic of respondents}

Respondents were dominated by men $(84.38 \%)$ as presented in Table 1 . Women activities related to beef cattle rearing was small $(16.62 \%)$. A lot of activities were needed to cut for grass, clean the cage and bath the cow were mostly done by their husband. Women only have a little time to rear beef cattle, such as feeding and drinking. In relation with beef cattle rearing, women have already burdened with domestic work such as caring children, cooking, washing, and cleaning the house,

On average, the age of respondents were 47.55 years old. The majority of respondents $(96.88 \%)$ were at the productive age. This indicated that the existing human resources strongly support the beef cattle farms. According to Sumiati (2011, age affects attitudes to learn, to understand innovations during a business, to increase productivity and physical skills to figure and ways in which of thinking.

Respondents spent 13.44 years at school. This indicated that respondents education were good. Farm experience of respondents was good because on average it was more than 5 years. Respondents have farm experience more than 10 years (53.13\%). Hendrayani (2009) argued that the expertise of farming/raising is a crucial capital for the success of a farming activity. The expertise of farmers is incredibly closely associated with their ability, the longer the expertise of raising somebody, the upper the standard of the abilities. Completely different levels of expertise of every farmer also will differ in their mentality in applying innovation in their farming activities.

The ownership of beef cattle was small (3.7 heads). Majority of respondents (96.88\%) have beef cattle less than 10 heads, this indicated that beef cattle farming is a people's farm.

\section{Attitude of Beef Cattle Farmer to Biosecurity}

Attitudes toward behavior showed the individual's analysis of behavior. The analysis of behavior could be positive or negative. Attitudes are evaluative statements about objects, people or events. This reflects a person's feelings for something (Robbin, 2007). 
Table 1. Characteristics of Beef Cattle Farmers

\begin{tabular}{lcc}
\hline \multicolumn{1}{c}{ Characteristics } & Percentage & Average \\
\hline Gender & & \\
- Men & 84.38 & \\
- Women & 15.62 & \\
Age (year) & & 47.55 \\
- $15-64$ (productive age) & 96.88 & \\
- $\quad$ 65 (unproductive age) & 3.12 & \\
Education level & & \\
- Elementary School & 56.25 & \\
- Junior High School & 28.13 & \\
$-\quad$ Senior High School & 15.62 & \\
Farm experience (year) & & \\
$-\quad 1-10$ & 46.87 & \\
- $\quad 10$ & 53.13 & \\
Number of beef cattle (head) & & \\
$-\quad<10$ & 96.88 & \\
$-\quad \geq 10$ & 3.12 & \\
\hline
\end{tabular}

Table 2 showed that respondents disagree if the application of biosecurity in accordance with the environmental conditions of local communities (53.28\%). The location of the barn was too close to the house. According to the requirements of a good barn, the location at least 10 meters away from house (Ministry of Agriculture, 2010).

Sixty two point zero six percent $(62.06 \%)$ of beef cattle farmers less agree if the application of biosecurity in accordance with farmers needs. As is known that farmers maintain beef cattle aimed at saving and can sell cattle at any time they need money. In fact, beef cattle breeders do not get a real advantage when implementing biosecurity. This results were supported by Julien and Thomson (2011) who argued that money incentives of biosecurity adoption aren't forever obvious.

Respondents agree that the application of biosecurity is complicated $(62.02 \%)$, because a lot of preparation and observation should be done, whereas in fact breeders have been pre occupied with the main activity on the paddy field. Then, $55.17 \%$ of respondents disagree that the application of biosecurity is easily observed, while in fact it takes time. Respondents agree that the application of biosecurity can be tested on a small scale (55.17\%), because the risk is small.

Respondents disagree if the application of biosecurity can increase beef production $(89.65 \%)$. The results of this study concordant with Ekowati et al. (2018) who argued that there have been several influencing factors of beef production such as breed, forage, concentrate, health, reproduction, labor, year of farming and enterprise implementation.

Respondents disagree if the application of biosecurity can improve the quality of meat (62.07\%). The result was supported by Mushi et al. (2007) who stated that there have been some factors that have an effect on to the standard of meat, such as smart farm animal practices in production chains as well as development and implementation of standards and code of conducts in feeding, transportation, slaughter meat sales and process chains.

Based on Table 2, in general respondents have less agree to biosecurity adoption. The results of this study were in accordance with the opinion of Brennan and Christley (2013) who stated that the majority producers felt the appointive biosecurity practices were in a way helpful, but there wasn't perpetually agreement between the quality of a observe and it being undertaken, and the other way around. Victor et 
al. (2013) found that alternative potential constraints for proper biosecurity adoption enclosed troublesome communication between farmers and their staff and guests, lack of information relating to infection routes, and monetary limitations.

\section{Behavior Based on Subjective Norms}

According to Ham et al. (2015), subjective requirements refer to the faith that a specific conduct is authorized and supported via an important character or team of people. Subjective requirements are determined via other people's perceived social stress to behave in a sure way and their motivation to comply with the views of these people. In general, the affect of subjective requirements on intention formation proved to be weaker.

Table 3 showed that based on subjective norms, beef cattle farmers agree to adopt biosecurity if supported by community leaders $(67.25 \%)$ and other livestock farmers or farmer groups $(77.25 \%)$. This means that community leaders and other farmers were the closest examples for beef cattle farmers. However, farmers disagree with government support $(70.14 \%)$ and family $(68.70 \%)$ in implementing biosecurity. The results of this research in contra with that of Maye et al. (2017) who argued that as things get additional unsure, government establishments became additional cogent. Government establishments and government veterinerians were additionally vital for farmers to take into account themselves 'experts' i.e.

Table 2. Attitude of Beef Cattle Farmers to Biosecurity

\begin{tabular}{lrrr}
\hline \multicolumn{1}{c}{ Statements } & Agree & $\begin{array}{c}\text { Less } \\
\text { Agree }\end{array}$ & Disagree \\
\hline & $\ldots \ldots \ldots \%$ & $\ldots \ldots$ \\
& 10.36 & 68.96 & 20.68 \\
Application of biosecurity give benefits to farmers & 44.83 & 51.72 & 3.45 \\
Application of biosecurity in accordance with local custom or culture & & & \\
Application of biosecurity in accordance with the environmental & 36.38 & 53.28 & 10.34 \\
conditions of local communities & 24.15 & 62.06 & 13.79 \\
Application of biosecurity in accordance with the needs of breeders & 62.03 & 24.83 & 14.13 \\
The application of biosecurity is complicated & 24.14 & 55.17 & 20.69 \\
Application of biosecurity is easily observed & 55.17 & 41.38 & 3.45 \\
Biosecurity applications can be tried on a small scale & 0 & 89.65 & 10.35 \\
Application of biosecurity may increase meat production & 20.69 & 62.07 & 17.24 \\
Application of biosecurity can improve the quality of beef & & &
\end{tabular}

Table 3. Beef Cattle Farmers' Behavior Based on Subjective Norms

\begin{tabular}{lccc}
\hline \multicolumn{1}{c}{ Supporting Institution, Groups or Individual } & Agree & Less agree & Disagree \\
\hline & $\ldots \ldots \ldots \ldots \ldots \ldots \ldots \ldots$ & $\ldots \ldots$ \\
1. Community leaders & 67.25 & 32.00 & 2.75 \\
2. Government & 28.34 & 70.14 & 1.50 \\
3. Family & 26.30 & 68.70 & 5.00 \\
4. Farmers or other farmers' group & 77.25 & 14.65 & 9.10 \\
\hline
\end{tabular}




\begin{tabular}{|c|c|c|c|}
\hline Statements & Agree & Less agree & Disagree \\
\hline & &.$\%$ & . \\
\hline 1. Time & 66.45 & & \\
\hline 2. Habit & & & 55.46 \\
\hline 3. Triabilitas & 70.20 & & \\
\hline 4. Compatabilitas & 62.36 & & \\
\hline 5. Prior implementation & & 73.33 & \\
\hline 6. Risk & & 67.24 & \\
\hline 7. Resource & 66.43 & & \\
\hline 8. Training & 68.34 & & \\
\hline 9. Informations & 58.67 & & \\
\hline
\end{tabular}

vaccination as against culling. Cardwell et al. (2016) stated that a collaboration between veterinerians and farmers, was valuable in encouraging improved biosecurity practices.

\section{Behavior Control}

Perceived behavioral management is outlined as perceived easy activity the behavior. it's influenced each by situational and internal factors that would inhibit or facilitate activity the behavior. The perceived activity management is influenced by the management belief and also the power of the relevant management belief. The expectancy-value framework might be accustomed live it quantitatively (Pawlak et al., 2008). Rehman et al. (2007) noted that attitudes of English farmers toward production technologies contend a vital role in their behavior intent, that was mirrored in their actual adoption behavior.

Table 4 showed that majority of respondents $(>50 \%)$ agree in behavior control of beef cattle farmers toward biosecurity adoption, because to implement biosecurity need a long time, can be tested on a small scale cattle business, according to the needs of cattle farmers, need workers, need knowledge, skills and information about biosecurity.

More than $50 \%$ of respondents stated that they less agree that implementing biosecurity need to prior implementation $(73.33 \%)$ and risky results $(67.24 \%)$ respectively. These were an inhibiting factors. Moreover, $55.46 \%$ of respondents disagree if the application of biosecurity was common as a habbit. In fact, respondents were not used to applying all biosecurity instruments. This finding was supported by Jover (2016) who stated that over fortieth of producers had restricted information concerning animal diseases. Solely a moderate implementation of biosecurity practices was reportable. Richens et al. (2018) added that farmers might be devided into 2 categories: people who did not apply biosecurity and people who applied biosecurity for a few time.

\section{CONCLUSION}

Based on theory of planned behavior, it can be concluded that beef cattle farmers showed a negative attitude to biosecurity. It can be suggested to motivate beef cattle farmers to adopt biosecurity in order to get a healthy meat and healthy community.

\section{REFERENCES}

Ajzen, I. (2002). Perceived behavioral control, self-efficacy, locus of control, and the theory of planned behavior. Journal of Applied Social Psychology. 32:665-683.

Azis, A. 2016. Kebijakan Umum Pembangunan Peternakan dalam Mendukung Peternakan Rakyat di Sulawesi Selatan. Proceedings of National Seminar on Animal Science, Universitas Hasanuddin, Makassar, 18 
September 2017.

Brennan, M. L. and R. M. Christley. 2013. Cattle producers' perceptions of biosecurity. BMC Vet. Res. 9:71

Cardwell, J. M., S. Van Winden, W. Beauvais, A. Mastin, W. A. De Glanville, J. Hardstaff, R. E. Booth, J. Fishwick and D. U. Pfeiffer. 2016. Assessing the impact of tailored biosecurity advice on farmer behaviour and pathogen presence in beef herds in England and Wales. Prev. Vet. Med.135:9-16.

Central Bureau of Statistics. 2017. South Sulawesi in Figure. Makassar.

Direktorat General of Livestock and Animal Health.2014. Peraturan Pemerintah Republik Indonesia No. 74 Tahun 2014 tentang Pengendalian dan Penanggulangan Penyakit Hewan. Department of Agriculture, Jakarta.

Dorea, F.C., R. Berghaus., C. Hofacre and D. J. Cole. 2010. Survey of biosecurity protocols and practices adopted by growers on commercial poultry farms in Georgia, U.S.A. Avian Diseases. 54(3):107-1015

Ekowati, T, E. Prasetyo and M. Handayani. 2018. The factors influencing production and economic efficiency of beef cattle farm in Grobogan Region, Central Java. J. Indonesian Trop. Anim. Agric. 43(1):76-84.

Gunn, G. J., C. Heffernan, M. Hall, A. McLeod and M. Hovic. 2008. Measuring and comparing constraints to improved biosecurity amongst GB farmers, veterinarians and the auxiliary industries. Prev. Vet. Med. 84(2-4): 310-323.

Ham, M., M. Jeger and A. F. Ivković. 2015. The role of subjective norms in forming the intention to purchase green food, Economic Research-Ekonomska Istraživanja. 28(1): 738-748.

Hendrayani. 2009. Analisis faktor-Faktor yang mempengaruhi motivasi berternak sapi di desa Koro Benai Kecamatan Benai Kabupaten Kuantan Singingi. J. Peternak. 6:53-62.

Herath, C. S. 2013. Does intention lead to behaviour? A case study of the Czech Republic farmers. Agric. Econ. Czech. 59(3):143-148.

Ibrahim, J. T. , A. Sudiyono dan Harpowo. 2003. Komunikasi dan Penyuluhan Pertanian. Banyumedia Publishing, UMM Press, Malang.

Jover, M. H., V. Higgins, M. Bryant, L. Rast and C. McShane. 2016. Biosecurity and the management of emergency animal disease among commercial beef producers in New South Wales and Queensland (Australia). Prev. Vet. Med. 134:92-102.

Julien, D and S. Thomson. 2011. Interactive methods to educate and engage poultry producers on the importance of practicing on-farm biosecurity. J. Agric. Ext. Rur. Dev. 3 (8):137-140.

Kementerian Pertanian. 2010. Petunjuk Praktis Perkandangan Sapi, Mataram: Balai Pengkajian Teknologi Pertanian NTB.

Mardikanto, T. 2009. Sistem Penyuluhan Pertanian. Sebelas Maret University Press. Surakarta.

Martojo, H. 2012. Indigenous Bali cattle is most suitable for sustainable small farming in Indonesia. Reprod. Dom. Anim. 47:10-14.

Maye, D., G. Enticott and R. Naylor. 2017. Using scenario-based influence mapping to examine farmers' biosecurity behavior. Land Use Policy. 66:265-277.

Mushi, D. E. , L. A. Mtenga and L. O. Eik. 2007. Some factors affecting the quality of meat from ruminants and their relevance to the Tanzanian meat industry - review. Tanzania J. Agric. Sc. 8(2):173-192.

Pawlak, R., D. Brown., M.K. Meyer, C. Connell, K. Yadrick, J.T. Johnson and A. Blackwell. 2008. Theory of planned behavior and multivitamin supplement use in Caucasian college females. Primary Prev. 29:57-71.

Robbins, S. P. 2007. Perilaku Organisasi Buku 1. Jakarta: Salemba Empat, Page 92-102.

Rehman, T., K. McKemey, C.M. Yates, R.J. Cooke, C.J. Garforth, R.B. Tranter, J.R. Park and P. T. Dorward. 2007. Identifying and understanding factors influencing the uptake of new technologies on dairy farms in SW England using the theory of reasoned action. Agricultural Systems 94:281-293.

Richens, I. F., J. Houdmont, W. Wapenaar, O. Shortall, J. Kaler, H.O'Connor and M.L. Brennan. 2018. Application of multiple behaviour change models to identify determinants of farmers' biosecurity attitudes and behaviours. Prev. Vet. Med.155:61-74.

Riduwan and Akdon. 2009. Rumus dan Data dalam Analisis Statistika. Alfabeta, Bandung.

Rogers, E. M. 2003. Diffusion of innovations (5th ed.). New York, NY: Free Press.

Satyanaraya, S.K.V.IAS., M. N. Reddy., N. 
Balasubramani., P. Chandrashekara., K.H. Rao and B.S. Santakki. 2008. Sustainable Livestock Development. National Institute of Agricultural Extension Management (MANAGE). Andhira Pradesh, India.

Siekkinen, K.K.M., J. Heikkilä, N. Tammiranta and H. Rosengren. 2012. Measuring the costs of biosecurity on poultry farms: a case study in broiler production in Finland. Acta Vet. Scand. 54(1):12.

Stankovie, B., S. Hristov, T. Petrujkie, J. Bojkovski, N. Maksimovie and N. Delie. 2011. Analysis of applied biosecurity measures in boars sperm production. Biotechnol. Anim. Husbandry. 27(2):209216.
Sumiati. 2011. Analisis Kelayakan Finansial dan Faktor-faktor yang Memotivasi Peternak dalam Kegiatan Agroforesti. Dissertation. Bogor Agricultural University, BogorIndonesia.

Toma, L., A. W. Stott, C. Heffernan, S. Ringrose and G. J. Gunn. 2013. Determinants of biosecurity behaviour of British cattle and sheep farmers - A behavioural economics analysis. Preventive Veterinary Medicine 108:321-333.

Victor, H. S. O., I. Anneberg, H. Voss, J. T. Sørensen and P. T. Thomsen. 2018. Attitudes of Danish dairy farmers towards biosecurity. Livest. Sci. 214:153-160. 